See discussions, stats, and author profiles for this publication at: https://www.researchgate.net/publication/11182070

\title{
Low prevalence of vancomycin-resistant enterococci in clinical samples from hospitalized patients of the Canary Islands, Spain
}

Article in International Microbiology · October 2002

DOI: 10.1007/s10123-002-0075-y · Source: PubMed

CITATIONS

14

11 authors, including:

Antonio Moreno

Hospital Clinico Universitario Virgen de la Arrixaca-IMIB

43 PUBLICATIONS 480 CITATIONS

SEE PROFILE

Jesus Villar

Hospital Universitario "Doctor Negrín"

351 PUBLICATIONS 9,291 CITATIONS

SEE PROFILE
READS

24

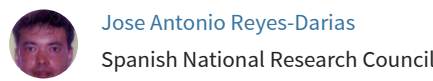

35 PUBLICATIONS 616 CITATIONS

SEE PROFILE

Manuel Macia

Hospital Universitario Nuestra Señora de Candelaria 115 PUBLICATIONS 1,236 CITATIONS

SEE PROFILE

Some of the authors of this publication are also working on these related projects:

iPROVE View project

Cyclin and CBS domain divalent metal cation transport mediators (CNNMs) and their cellular partners View project 


\author{
Xiomara Pérez-Hernández · Sebastián Méndez-Álvarez \\ Teresa Delgado · Antonio Moreno \\ Jose Antonio Reyes-Darias · Antonio Sierra López \\ Jesús Villar · Agustín González \\ Antonio Manuel Martín Sánchez · Manuel Macía \\ Félix Claverie-Martín
}

\title{
Low prevalence of vancomycin-resistant enterococci in clinical samples from hospitalized patients of the Canary Islands, Spain
}

Received: 4 April 2002 / Accepted: 8 May 2002 / Published online: 26 June 2002

(C) Springer-Verlag and SEM 2002

\begin{abstract}
Over the last decade vancomycin-resistant enterococci (VRE) have emerged as nosocomial pathogens. The aim of this study was to determine the prevalence of VRE in clinical samples from hospitalized
\end{abstract}

X. Pérez-Hernández · S. Méndez-Álvarez · J.A. Reyes-Darias J. Villar · M. Macía $\cdot$ F. Claverie-Martín $(\square)$

Research Unit,

Hospital Universitario Ntra. Sra. de Candelaria,

38010 Santa Cruz de Tenerife, Spain

E-mail: fclamar@gobiernodecanarias.org

Tel.: + 34-922-600675

Fax: + 34-922-600562

S. Méndez-Álvarez

Department of Cellular Biology and Microbiology,

University of La Laguna,

La Laguna, Spain

M. Macía

Nephrology Service,

Hospital Universitario Ntra. Sra. de Candelaria,

La Laguna, La Laguna, Spain

T. Delgado · A. Sierra López

Microbiology Service,

Canarian University Hospital,

Santa Cruz de Tenerife, Spain

\section{A. Moreno}

Microbiology Service,

Hospital Universitario Ntra. Sra. de Candelaria,

Santa Cruz de Tenerife, Spain

\section{A. González}

Microbiology Service,

Hospital Dr. Negrín,

Las Palmas de Gran Canaria, Spain

A.M. Martín Sánchez

Microbiology Service,

Hospital Insular,

Las Palmas de Gran Canaria, Spain

Present address: X. Pérez-Hernández

Unidad de Investigación,

Hospital Dr. Negrín,

Las Palmas de Gran Canaria, Spain patients in the Canary Islands. From April to November 2000, 437 enterococci were isolated from patients hospitalized at the four main health care centers in those islands. Identification to the species level was performed with the GPS-TA (Vitek 1) or the Wider I system. A PCR assay was used to determine the genotype of glycopeptide resistance (van A, van B, vanC1, and $\operatorname{van} C 2 / C 3$ genes). Only three $(0.7 \%)$ VRE were detected: one van $A$ Enterococcus faecalis, and two vanCl Enterococcus gallinarum. To our knowledge, this is the first VRE study carried out in the Canary Islands hospitals, and the results showed a low prevalence of VRE.

Keywords Enterococcus - Prevalence - Glycopeptide · Antibiotic resistance

\section{Introduction}

Vancomycin-resistant enterococci (VRE) have emerged as a major cause of nosocomial infections [2, 13, 14, 21]. Since their initial isolation from patients in the United Kingdom and France, VRE infections have been increasingly detected throughout the world [23]. These bacteria are often resistant to multiple antibiotics, thus limiting the number of therapeutic options available to the physician [9]. Among isolates from United States hospitals, resistance to vancomycin rose from $0.3 \%$ in 1989 to $15.4 \%$ in 1997 [5, 14]. In contrast, the prevalence of VRE in European hospitals is low, being $1.8 \%$ in Spain [3, 22].

Vancomycin is a member of a class of antibiotics referred to as glycopeptides. These antibiotics interfere with peptidoglycan biosynthesis by binding to the terminal D-alanyl-D-alanine residue of the peptidoglycan precursor [23]. Seven glycopeptide resistance genotypes have been described in enterococci $[2,12,13]$. Five of these (van $A, \operatorname{van} B, \operatorname{van} D, \operatorname{van} E$ and $\operatorname{van} G)$ are acquired mechanisms and the other two (vanC1 and vanC2/C3) 
are intrinsic properties. The van $A$ and $\operatorname{van} B$ resistance genotypes are the most commonly found. The van $A$ gene cluster encodes proteins that confer high-level resistance to both vancomycin and teicoplanin [1]. The expression of vanA genes is induced by either vancomycin or teicoplanin. The $\operatorname{van} B$ genes confer resistance to various concentrations of vancomycin but not teicoplanin [6, 13], and are induced only by vancomycin and not by teicoplanin. The VanA phenotype is distributed worldwide, and is by far the predominant type of vancomycin resistance reported in Europe [20]. Although VanA is the predominant type, VanB strains are fairly common in the Unites States [2]. The vanC1 and vanC2/C3 genes are specific to the motile VRE species Enterococcus gallinarum and E. casseliflavus/E. flavescens, respectively [4]. The other genotypes, vanD, vanE and $v a n G$, have been detected in only a few enterococcal strains $[8,12,16,19]$.

In this report, we provide data on the prevalence of VRE in clinical samples from hospitalized patients in the Canary Islands. These islands, which constitute an autonomous region of Spain, are located in the Atlantic ocean off the coast of North-West Africa, and have a population of approximately 1,700,000. In our hospitals, vancomycin is frequently prescribed due to the high prevalence of methicillin-resistant Staphylococcus aureus [18]. To our knowledge, this is the first study on VRE carried out in the Canary islands.

\section{Materials and methods}

Patients, bacterial isolates and reference strains

The four main hospitals in the Canary Islands are 500- to 900-bed health care centers, two of which are located in the island of Tenerife (Nuestra Señora de Candelaria University Hospital and Canarian University Hospital) and the other two in the island of Gran Canaria (Dr. Negrín Hospital and Insular Hospital). These hospitals provide tertiary care for most of the population of the islands. During a 9-month period (April-November 2000), we studied 406 enterococcal clinical isolates collected from patients hospitalized at the four hospitals. A single specimen was obtained from each subject. The isolations, approximately 100 per hospital, were carried out by the Microbiology Service of each hospital. The isolates from clinical samples came from urine (173), wounds (118), blood (46), catheter tips (29), respiratory tract (13), and other clinical materials (27). A total of 31 colonizers, isolated from rectal cultures in adults, were also included in the study. The following reference strains were used: E. faecium BM4147 (vanA), E. faecalis V583 (vanB), E. gallinarum BM4174 (vanC1), E. casseliflavus ATCC 25788 (vanC2), and E. faecalis ATCC 29212 as a glycopeptide-susceptible control. S. aureus ATCC 29213 was used as a negative control.
Phenotypic identification and susceptibility testing

Bacterial isolates were processed by agar bile-esculin-vancomycin $(6 \mu \mathrm{g} / \mathrm{ml})$ screening to detect enterococcal colonies and vancomycin resistance. Isolates were identified to the species level with the GPSTA (Vitek 1) system (bioMérieux, Marcy l'Etoile, France) except those from the Hospital Insular (Las Palmas de Gran Canaria), which were identified with the Wider I System (Dade Microscan, West Sacramento, Calif.). The minimal inhibitory concentrations (MIC) of vancomycin and teicoplanin for the resistant isolates were determined by broth microdilution according to National Committee for Clinical Microbiology Standards guidelines [15]; both antibiotics were tested in the range $0.25-128 \mu \mathrm{g} / \mathrm{ml}$. VRE were also tested with the E-test method (AB Biodisk, Solna, Sweden) according to the manufacturer's specifications. Biochemical identification of enterococci was performed according to standard laboratory criteria [7].

\section{PCR amplification}

We used a previously described PCR protocol for the simultaneous detection of the most common vancomycin-resistance genotypes (van $\mathrm{A}, \operatorname{van} B, \operatorname{van} C 1$ and $\operatorname{van} C 2 / C 3)$ and identification of Enterococcus isolates at the genus level [17]. Strains were grown overnight at $37^{\circ} \mathrm{C}$ on blood sheep agar plates (bioMérieux, Marcy l'Etoile, France). Three to five colonies of each sample were scraped from the surface of the agar and resuspended in $1 \mathrm{ml}$ of sterile distilled water. The cell suspension was heated to $100^{\circ} \mathrm{C}$ for $15 \mathrm{~min}$ and was then centrifuged at $15,000 \mathrm{~g}$ for $10 \mathrm{~min}$. The DNA-containing supernatant was used as a template. An aliquot of $20 \mu \mathrm{l}$ of the supernatant was added to $80 \mu \mathrm{l}$ of a PCR mixture consisting of $1 \times$ reaction buffer [16 mM $\left(\mathrm{NH}_{4}\right)_{2} \mathrm{SO}_{4}, 67 \mathrm{mM}$ Tris-HCl, pH 8.8], $0.2 \mathrm{mM}$ of each deoxyribonucleotide triphosphate (Promega, Madison, Wis.), $2.5 \mathrm{mM} \mathrm{MgCl} 2,50 \mathrm{pmol}$ of each primer, and 1.2 U Taq DNA polymerase (Bioline, UK). For each sample, the $\mathrm{PCR}$ reaction was performed with the $\operatorname{van} \mathrm{A}, \operatorname{van} \mathrm{B}, \operatorname{van} \mathrm{C} 1$, $\operatorname{van} \mathrm{C} 2$ C3 and Ent pairs of primers (Roche, Mannheim, Germany) in a single tube $[4,10,17]$. A negative control without DNA template was included in the assay. DNA amplification was carried out in a GeneAmp PCR system 9700 thermocycler (PE Applied Biosystems, Calif.) with the following thermal cycling profile: an initial denaturation step at $94^{\circ} \mathrm{C}$ for 2 min was followed by 25 cycles of amplification $\left(94^{\circ} \mathrm{C}\right.$ for $60 \mathrm{~s}, 55^{\circ} \mathrm{C}$ for $60 \mathrm{~s}$, and $72^{\circ} \mathrm{C}$ for $60 \mathrm{~s}$ ), and an extension at $72^{\circ} \mathrm{C}$ for 5 min. PCR products were resolved by electrophoresis on a $1.5 \%$ agarose gel stained with ethidium bromide. A 100-bp DNA ladder (Roche, Mannheim, Germany) was run in each gel, and the VRE genotype was determined by the size of the amplified product.

\section{Results and discussion}

A total of 437 enterococci isolates were obtained from clinical samples in the four main hospitals of the Canary Islands. Table 1 shows their phenotypic identification. E. faecium was the most abundant species $(86.2 \%)$. The two E. gallinarum isolates had been initially identified as
Table 1. Enterococcal isolates and vancomycin resistance genotypes

\begin{tabular}{lcll}
\hline Species & $\begin{array}{l}\text { No. }(\%) \\
\text { of isolates }\end{array}$ & $\begin{array}{l}\text { No. of vancomycin- } \\
\text { resistant enterococci (VRE) }\end{array}$ & $\begin{array}{l}\text { Resistance } \\
\text { genotype (\%) }\end{array}$ \\
\hline Enterococcus faecalis & $377(86.3)$ & 1 & vanA $(0.2)$ \\
E. faecium & $52(11.9)$ & 0 & - \\
E. avium & $4(0.9)$ & 0 & - \\
E. durans & $2(0.5)$ & 0 & - \\
E. gallinarum & $2(0.5)$ & 2 & vanC1 $(0.5)$ \\
Total & $437(100)$ & 3 & van $(0.7)$ \\
\hline
\end{tabular}


E. faecium and Enterococcus sp. with the automated system. Further biochemical and motility tests identified them as E. gallinarum. Three VRE $(0.7 \%)$ were detected: one E. faecalis (UIE-478, isolated from blood of a cancer patient who had had vancomycin treatment) and the two E. gallinarum (UIE-298 and UIE-470, isolated from a new-born ear infection and a post-surgery abscess, respectively). The automated system detected high-level resistant isolates (VanA phenotype), but not low-level resistant isolates (VanC phenotype). Using the agar dilution method, E. faecalis UIE-478 showed high-level resistance to vancomycin (MIC $>128 \mu \mathrm{g} / \mathrm{ml}$ ) and to teicoplanin (MIC $>128 \mu \mathrm{g} / \mathrm{ml}$ ), whereas E. gallinarum UIE-470 and E. gallinarum UIE-298 showed low-level vancomycin resistance ( $\mathrm{MIC}=8 \mu \mathrm{g} / \mathrm{ml}$ ) and teicoplanin (MIC $=1 \mu \mathrm{g} / \mathrm{ml})$ susceptibility. By the E-test method, E. faecalis UIE-478 had MICs of $>256 \mu \mathrm{g} / \mathrm{ml}$ for vancomycin and $128 \mu \mathrm{g} / \mathrm{ml}$ for teicoplanin; E. gallinarum UIE-470 had MICs of $8 \mu \mathrm{g} / \mathrm{ml}$ for vancomycin and $0.38 \mu \mathrm{g} / \mathrm{ml}$ for teicoplanin; and E. gallinarum UIE-298 had MICs of $4 \mu \mathrm{g} / \mathrm{ml}$ for vancomycin and $0.25 \mu \mathrm{g} / \mathrm{ml}$ for teicoplanin. The VanA isolate, E. faecalis UIE-478, was sensitive to penicillin-G, high concentrations of gentamicin, and high levels of streptomycin, and therefore did not represent a problem during treatment.

The results of the PCR assay with the 437 enterococcal isolates were in accordance with the phenotypic characterization. Three VRE were detected (Table 1): one vanA isolate, E. faecalis UIE-478, and two vanC1 isolates, E. gallinarum UIE-298 and UIE-470. The PCR results obtained with reference strains $E$. faecium BM4147 (vanA) and E. gallinarum BM4174 (vanC1) were as expected (not shown). The rest of the clinical isolates were all negative for the $\operatorname{van} A, \operatorname{van} B, \operatorname{van} C 1$ and $\operatorname{van} C 2 / C 3$ genes (results not shown). The $\operatorname{van} B$ gene was not detected in any of the isolates.

In conclusion, this is the first study of VRE isolated from clinical samples from hospitalized patients in the Canary Islands, and the results show a low prevalence $(0.7 \%)$ of VRE $(0.2 \%$ for vanA gene and $0.5 \%$ for vanCl gene). This prevalence was lower than that reported in other European countries and in the United States [2, 11, 14, 22, 23]. Results of a recent VRE study in Europe have shown that the United Kingdom has the highest prevalence $(2.9 \%)$, while other European countries have prevalence rates of $1 \%$ or lower. In Spain, a multicenter study that did not include the Canary Islands showed that the rate of resistance to glycopeptides was $1.8 \%$ [3]. E. gallinarum and E. casseliflavus isolates are not always taken into account because their resistance to glycopeptides is intrinsic and their pathogenesis is very low. In our study, if we take out the two vanC1 E. gallinarum, the prevalence of VRE would be $0.2 \%$, which is even lower than previously reported levels [22].

Acknowledgements We thank Dr. Nadia Liassine, Central Laboratory of Bacteriology, University Hospital, Geneva, for providing reference strains. This work was supported by grants 1999/074 and 2001/020 from the Consejería de Educación, Cultura y Deportes,
Canary Island Autonomous Government, and FUNCIS PI 40/00, Canary Island Autonomous Government to F.C.M., S.M.A. and M.M. Work by S.M.A. was supported by FIS contract 99/3060 (Fondo de Investigación Sanitaria, Spain).

\section{References}

1. Arthur M, Reynolds P, Courvalin P (1996) Glycopeptide resistance in enterococci. Trends Microbiol 4:401-407

2. Cetinkaya Y, Falk P, Mayhall CG (2000) Vancomycin-resistant enterococci. Clin Microbiol Rev 13:686-707

3. Cisterna R, Ibarra K, Morla A, Basaras M, Cisterna C, Herreras A, Borja J, Grupo Español de Estudio y Vigilancia de Resistencias (1999) Estudio multicéntrico de resistencias en enterococos. Papel de la teicoplanina. Rev Esp Quimioter $12: 237-243$

4. Dutka-Malen S, Evers S, Courvalin P (1995) Detection of glycopeptide resistance genotypes and identification to the species level of clinically relevant enterococci by PCR. J Clin Microbiol 33:24-27

5. Endtz HP, van den Braak N, Verbrugh HA, van Belkum A (1999) Vancomycin resistance: status quo and quo vadis. Eur J Clin Microbiol Infect Dis 18:683-690

6. Evers S, Courvalin P (1996) Regulation of VanB-type vancomycin resistance gene expression by the $\operatorname{VanS}_{\mathrm{B}}-\operatorname{VanR}_{\mathrm{B}}$ twocomponent regulatory system in Enterococcus faecalis V583. J Bacteriol 178:1302-1309

7. Fackland RR, Sham DF, Teixeira LM (1999) Enterococcus. In: Murray PR, Baron EJ, Pfaller MA, Tenover FC, Yolken RH (eds) Manual of clinical microbiology, 7th edn. American Society for Microbiology, Washington, D.C., pp 297-305

8. Fines M, Perichon B, Reynolds P, Sahm DF, Courvalin P (1999) VanE, a new type of acquired glycopeptide resistance in Enterococcus faecalis BM4405. Antimicrob Agents Chemother 43:2161-2164

9. Gold HS (2001) Vancomycin-resistant enterococci: mechanism and clinical observations. Clin Infect Dis 33:210-219

10. Ke D, Picard FJ, Martineau F, Ménard C, Roy PH, Ouellette M, Bergeron MG (1999) Development of a PCR assay for rapid detection of enterococci. J Clin Microbiol 37:3497-3503

11. Low DE, Keller N, Barth A, Jones RN (2001) Clinical prevalence, antimicrobial susceptibility, and geographic resistance patterns of enterococci: results from the SENTRY antimicrobial surveillance program, 1977-1999. Clin Infect Dis 15 [Suppl 2]: S133-145

12. McKessar SJ, Berry AM, Bell JM, Turnidge JD, Paton JC (2000) Genetic characterization of vanG, a novel vancomycin resistance locus of Enterococcus faecalis. Antimicrob Agents Chemother 44:3224-3228

13. Méndez-Alvarez S, Pérez-Hernández X, Claverie-Martín $F$ (2000) Glycopeptide resistance in enterococci. Int Microbiol 3:71-80

14. Murray BE (2000) Vancomycin-resistant enterococcal infections. N Engl J Med 342:710-721

15. National Committee for Clinical Microbiology Standards (1997) Performance standards for antimicrobial susceptibility tests. Approved standard M2-A6. National Committee for Clinical Laboratory Standards, Villanova, $\mathrm{Pa}$.

16. Ostrowsky BE, Clark NC, Thauvin-Eliopoulus C, Venkataraman L, Samore MH, Tenover FC, Eliopoulus GM, Moellering RC Jr, Gold HS (1999) A cluster of VanD vancomycinresistant Enterococcus faecium: molecular characterization and clinical epidemiology. J Infect Dis 180:1177-1185

17. Pérez-Hernández X, Méndez-Álvarez S, Claverie-Martín $F$ (2002) A rapid PCR assay for rapid detection of vancomycinresistant enterococci. Diagn Microbiol Infect Dis 42:273-277

18. Pérez-Roth E, Claverie-Martín F, Batista N, Moreno A, Méndez-Alvarez S (2002) Mupirocin resistance in methicillin resistant Staphylococcus aureus clinical isolates in a Spanish hospital. Co-application of multiplex PCR assay and conven- 
tional microbiology methods. Diagn Microbiol Infect Dis 43 (in press)

19. Périchon B, Reynolds P, Courvalin P (1997) VanD-type glycopeptide-resistant Enterococcus faecium BM4339. Antimicrob Agents Chemother 41:2016-2018

20. Peset V, Tallon P, Sola C, Sanchez E, Sarrion A, Perez-Belles C, Vindel A, Canton E, Gobernado M (2000) Epidemiological, microbiological, clinical and prognostic factors of bacteremia caused by high-level vancomycin-resistant Enterococcus species. Eur J Clin Microbiol Infect Dis 19:742-749
21. Rice LB (2001) Emergence of vancomycin-resistant enterococci. Emerg Infect Dis 7:183-187

22. Schouten MA, Hoogkamp-Korstanje JAA, Meis JFG, Voss A, The European VRE Study Group (2000) Prevalence of vancomycin-resistant enterococci in Europe. Eur $\mathbf{J}$ Clin Microbiol Infect Dis 19:816-822

23. Woodford N (1998) Glycopeptide-resistant enterococci: a decade of experience. J Med Microbiol 47:849-862 